Managing Complex Multinational Enterprises: Internal Network Structure and Expatriation Strategies

\author{
Jong Min Lee
}

Ph.D. awarded by University of Reading, UK (September 2016)

\section{BIG Question:}

"How do multinational enterprises configure crucial managerial resources such as expatriates across the portfolio of differentiated subsidiaries?"

\section{Introduction}

Over the last two decades, the view of the multinational enterprise (MNE) as a "differentiated network" has become dominant in international business (IB) literature. The MNE is conceptualized as a network or a portfolio of differentiated subsidiaries, in which each subunit commands an idiosyncratic set of resources in a specific location, having reciprocal and sequential interdependencies with other MNE subunits (Nohria \& Ghoshal, 1997). The differentiated network view has drawn significant attention to the complex nature of the MNE, particularly those to do with the associated control and coordination issues (Ghoshal \& Bartlett, 1990). Having subsidiaries with their own set of competences creates the possibility that MNEs can, in principle, take advantage of the diversity of knowledge from various locations. However, it may necessarily lead to a loosening of central control of corporate headquarters (HQ) over subsidiaries, which in turn, entails more sophisticated control and coordination problems than the economic-based IB literature has thus far suggested (Meyer, Mudambi, \& Narula, 2011).

More recently, MNE activities have become unprecedentedly fine-grained and dispersed across a range of locations. Many MNEs now deal with a large portfolio of differentiated subsidiaries, facing a rapid escalation of complexity as the biggest managerial challenge. IB literature has increasingly recognized that the managerial capability of MNE HQ to effectively man- age complex organizational networks is a key source of competitive advantages in today's multinationals (Forsgren, Holm, \& Johanson, 2005; Narula, 2014). However, despite such growing recognition, very few studies have explicitly explored this management issue in a complex MNE setting, and little is known about how MNEs (or HQ) effectively manage a complex portfolio of differentiated subsidiaries dispersed a range of locations.

The objective of this thesis is to advance our knowledge as to this critical management inquiry by investigating how MNEs configure crucial managerial resources, viz., expatriates, across their complex internal network or subsidiary portfolio. Expatriation, functioning as an extended form of HQ control and a reliable intermediary of firm-specific knowledge, provides HQ with a key mechanism to effectively manage their international operation from a distance (Harzing, 2001). Expatriate utilization is, therefore, closely associated with the management quality and the ability to manage a multinational network that further affect MNE performance (Verbeke \& Forootan, 2012).

This thesis maintains that MNE structural attributes which reflect the degree of internal differentiation within the subsidiary portfolio determine the level of managerial complexity faced by $\mathrm{HQ}$, and hence, affect expatriate staffing strategies. Given that expatriates are a unique but limited managerial resource of the $\mathrm{MNE}$, expatriate configuration across the subsidiary portfolio is indeed a resource allocation decision for HQ that should reflect different contingencies presented by each subsidiary context as well as the overall subsidiary portfolio characteristics. This thesis extends the literature on international management and expatriation by presenting theoretical arguments and evidence on the important role of the MNE's internal network structure in HQ managerial decision-making, particularly in relation to expatriate utilization. 


\section{Summary of the Thesis}

Based on the differentiated network view of the MNE (Nohria \& Ghoshal, 1997) and the organization theory of structural complexity (Blau \& Schoenherr, 1971; Hall, 1977), this thesis theorizes that the level of managerial complexity faced by HQ is directly associated with the 'internal network structure' of the MNE which reflects to what extent the entire subsidiary portfolio is internally differentiated (Ghoshal \& Nohria, 1989). In particular, the thesis highlights that the internal network structure of the MNE represents the degree of internal differentiation across three different dimensions, namely, (i) spatial dispersion (i.e., the extent to which an MNE operates in different national and regional - supranational - contexts), (ii) horizontal differentiation (i.e., the extent to which an MNE has subsidiaries with different value chain activities), and (iii) hierarchical differentiation (i.e., the extent to which power within an MNE is distributed across constituent subsidiaries). Based on this theoretical argument, the thesis demonstrates that the structural attributes of the MNE's internal network (which can also be referred as subsidiary portfolio characteristics) are associated with HQ managerial decisions related to expatriate utilization across the subsidiary portfolio.

A multifaceted investigation of 130 Korean MNEs and their 2,119 overseas subsidiaries (a nested dataset) operating in 77 countries across 7 regions (i.e., Africa, Asia, Europe, Middle East, North America, South America and Oceania) reveals that expatriation strategies employed by the MNE vary considerably upon the MNE's internal network structure, corroborating the main argument of this thesis. Three empirical papers included in the thesis scrutinize various aspects of the MNE's internal network structure and their influences on expatriation strategies, at the level of both the MNE as a whole and the subsidiary. The thesis utilizes two different theoretical frameworks to explain the rationale behind the MNE's expatriation decisions: the 'growth theory of the firm' which highlights the role of managerial resource constraints in firm growth (Penrose, 1959) and "behavioral theories of the firm" such as resource dependence theory (Pfeffer \& Salancik, 1978) and organizational learning theory (Levitt \& March, 1988) whose importance in IB research has been continually and increasingly emphasized due to the dynamic HQ-subsidiary relationship.

The first paper of the thesis investigates the influence of three structural attributes of the MNE's internal network such as (i) multinationality (the breadth of international activities at national level), (ii) power structure (the degree of power distribution across subsidiaries), and (iii) regional dependence (the degree to which MNE activities are concentrated in a certain region) on two different phases of expatriation strategies at the MNE level, namely, the overall intensity of expatriate utilization in the subsidiary portfolio and the variation of expatriation levels across constituent subsidiaries. The empirical results indicate that three structural attributes have significant impli- cations on expatriation strategies. MNEs with high multinationality and high regional dependence tend to utilize less intensive and more homogeneous (i.e., less variable) expatriation in their subsidiaries. MNEs with a more oligopolistic power structure (in which power within the MNE is concentrated on a small number of subsidiaries) tend to employ more intensive expatriation across all constituent subsidiaries, compared to MNEs with a more egalitarian power structure (in which power within the MNE is more equally distributed across all subsidiaries). These findings demonstrate that MNE structural attributes serve as crucial determinants of HQ expatriate utilization in the subsidiary portfolio. This study extends international management literature by theorizing and testing that the MNE's expatriation strategies are directly tied to the complexities stemming from MNE structure as well as to the managerial resource constraint at $\mathrm{HQ}$.

The second paper examines the MNE's expatriate staffing strategies at the subsidiary level, particularly focusing on the role of three variables derived from both $\mathrm{MNE}$ and subsidiary levels. This study, therefore, employs a multi-level analysis to investigate how the MNE's multinationality and home-region orientation (MNE level variables) and subsidiary age (subsidiary level variable) affect expatriate staffing levels in subsidiaries. The main objective of this paper is to examine how MNEs achieve the "differentiated fit" (Nohria \& Ghoshal, 1994) with their subsidiaries through expatriation. HQ simultaneously deals with a number of subsidiaries that represent different contingencies and hence require differentiated governing mechanisms. A range of factors may represent different contingencies that each subsidiary context exhibits, but the duration of business operations in a particular local context (i.e., subsidiary age) may play a major role as it closely relates to the subsidiary's local experience, learning, knowledge, power and the degrees of both internal and external embeddedness. The empirical results show that the MNE's multinationality and home-region orientation are negatively associated with expatriate staffing levels in subsidiaries, whereas subsidiary age has a U-shaped relationship, indicating that MNEs utilize intensive expatriation in their young and old subsidiaries for different reasons while employing less intensive expatriation in their adolescent subsidiaries. These findings enhance our understanding of managing differentiated network MNEs by empirically demonstrating how MNEs configure limited managerial resources (i.e., expatriates) to "fit" the differentiated and dynamic relationships with their subsidiaries, contingent on varying degrees of the MNE's spatial dispersion.

Finally, the third paper focuses on the MNE's spatial dispersion at both country and regional levels and its influence on expatriation decisions. Specifically, this paper presents a novel classification of four internationalization patterns (as presented in Figure 1) accounting for both intra- and inter-regional diversification (i.e., country and regional level diversification), and further examines their peculiar characteristics and distinct 
effects on expatriation decisions. The empirical findings from regression and clustering analyses suggest that intra- and inter-regional diversification has conflicting influences on expatriation strategies, such that intra-regional diversification is negatively associated with intensive expatriation while inter-regional diversification is positively related to intensive expatriation. These findings indicate that the effect of international diversification on managerial decisions (i.e., expatriate utilization) can be strengthened or weakened by the combination of both country and regional level diversification. This study extends the literature on internationalization and regionalization by demonstrating that intra- and inter-regional diversification plays distinctive roles in managerial decision-making, and that regional diversification actually affects the MNE's managerial costs and decisions, which has been a prevalent idea but rarely tested by empirical literature.

\section{Figure 1. Four Patterns of International Geographic Diversification}

\begin{tabular}{|c|c|c|c|}
\hline \multirow{4}{*}{$\begin{array}{l}\text { Intra-regional } \\
\text { diversification } \\
\text { (Multi-nationality) }\end{array}$} & High & Regiocentric & Cosmopolitan \\
\hline & \multirow[t]{3}{*}{ Low } & Concentrator & Market-picker \\
\hline & & Low & High \\
\hline & & \multicolumn{2}{|c|}{$\begin{array}{l}\text { Inter-regional diversification } \\
\text { (Multi-regionality) }\end{array}$} \\
\hline
\end{tabular}

\section{Contributions to Theory and Practice}

This thesis makes several important contributions to both theory and practice. First, this research enhances our knowledge of international management by scrutinizing the role of MNE structural attributes in HQ managerial decision-making. The contents of this thesis are multidisciplinary, linking IB with organization theories and international human resource management (IHRM). In particular, it has been a general observation in the literature that IB and IHRM have been evolving in parallel for many years. This thesis manages to systematically link these two related fields, providing important new insights that may survive the test of time.

Second, this thesis contributes to the expatriation literature by illustrating the dynamic aspects of expatriation strategies employed by MNEs. It demonstrates that capability development at the subsidiary level changes the subsidiary's power relation vis-à-vis $\mathrm{HQ}$ and hence ultimately affects HQ managerial de- cisions related to expatriate utilization. By shedding light on overall expatriate configuration across the entire subsidiary portfolio from the perspective of the MNE as a whole, this thesis also extends the literature that has typically focused on identifying the determinants of the appropriate expatriate staffing levels in individual subsidiaries.

Third, the thesis advances the literature on internationalization by confirming various effects of regional diversification on HQ managerial decisions. Moreover, the categorization of four internationalization patterns developed in this thesis provides a useful framework to examine the assorted implications of firm international diversification.

Fourth, the portfolio approach employed in this thesis provides theoretical, methodological and managerial implications to current IB and MNE literature. The extant literature has focused on the individual, dyadic HQ-subsidiary relationship, but neglected the fact that, in reality, MNE HQ perceive the subsidiary circumstance in a relative basis compared to other subsidiaries within the MNE, rather than in an absolute basis. This thesis provides support for the importance of conceptualizing the MNE as a portfolio, which allows to capture more holistic and realistic aspects of MNE management.

Finally, this thesis has some practical implications for the managers of the MNE, particularly those at HQ. The findings of the thesis highlight that managers should be aware that the structure of the MNE network may significantly affect their managerial decision-making, and accordingly, they should diagnose whether their current structure of the subsidiary portfolio fits their business and strategies. Moreover, HQ managers should note that subsidiary learning changes the subsidiary's power base within the MNE and ultimately alters its relationship vis-à-vis HQ. Therefore, managers at HQ must properly respond to such dynamic relationships with subsidiaries in order to maintain appropriate control while utilizing competences developed by subsidiaries for the whole MNE. This thesis suggests that expatriation provides HQ with an effective mechanism to respond to dynamic and differentiated HQ-subsidiary relationships, which is essential for managing complex MNEs.

\section{References}

Blau, P. M., \& Schoenherr, R. A. 1971. The structure of organisations. New York: Basic Books.

Forsgren, M., Holm, U., \& Johanson, J. 2005. Managing the embedded multinational: A business network view. Cheltenham, UK: Edward Elgar Publishing.

Ghoshal, S., \& Bartlett, C. A. 1990. The multinational corporation as an interorganizational network. Academy of Management Review, 15(4): 603-626. 
Ghoshal, S., \& Nohria, N. 1989. Internal differentiation within multinational corporations. Strategic Management Journal, 10(4): 323-337.

Hall, R. H. 1977. Organizations: Structure and process: Prentice-Hall International.

Harzing, A.-W. 2001. Of bears, bumble-bees, and spiders: The role of expatriates in controlling foreign subsidiaries. Journal of World Business, 36(4): 366-379.

Levitt, B., \& March, J. G. 1988. Organizational learning. Annual Review of Sociology, 14(1): 319-340.

Meyer, K. E., Mudambi, R., \& Narula, R. 2011 . Multinational enterprises and local contexts: The opportunities and challenges of multiple embeddedness. Journal of Management Studies, 48(2): 235-252.

Narula, R. 2014. Exploring the paradox of competence-creating subsidiaries: Balancing bandwidth and dispersion in MNEs. Long Range Planning, 47(1-2): 4-15.

Nohria, N., \& Ghoshal, S. 1994. Differentiated fit and shared values: Alternatives for managing headquarters-subsidiary relations. Strategic Management Journal, 15(6): 491-502.

Nohria, N., \& Ghoshal, S. 1997. The differentiated network: Organizing multinational corporations for value creation. San Francisco, CA: Jossey-Bass Publishers.

Penrose, E. T. 1959. The theory of the growth of the firm. Oxford, UK: Oxford University Press.

Pfeffer, J., \& Salancik, G. R. 1978. The external control of organizations: A resource dependence perspective. New York: Harper \& Row.

Verbeke, A., \& Forootan, M. Z. 2012. How good are multinationality-performance (m-p) empirical studies? Global Strategy Journal, 2(4): 332-344.

Jong Min Lee (jongmin.lee@henley.ac.uk) is a Lecturer/Assistant Professor of International Business and Strategy at Henley Business School, University of Reading, where he received his Ph.D. His current research focuses on the structures, strategies and management of multinational enterprises, with particular emphasis on the dynamic and differentiated relationship between headquarters and subsidiaries. His research interests also include knowledge management in multinational firms and the rise of emerging market multinationals. 